\title{
PERSPEKTIF AGAMA DAN KEBUDAYAAN DALAM KEHIDUPAN MASYARAKAT INDONESIA (Suatu Tinjauan Sosiologi Agama)
}

\author{
Laode Monto Bauto, Jurusan Sosiologi FISIP Universitas Haluoleo Kendari \\ Email: laodemonto@yahoo.co.id
}

\begin{abstract}
The relationship of religion, culture and community very important or is a system of life because of the interconnectedness of each other. But the question of keberagamaan and social development will not be complete if only seen from one particular aspect only. For that in looking at the question of societal must go through a holistic approach. Required studies as the study of the sociology of religion and vice versa. It means the study of the life of keberagamaan the community won't be completed without involving sociology, sociological stats helper monkeys do not judge the religion concerned. Each nation or group that actually live up to the mandate of each religion, therefore by itself will manifest harmony, brotherhood, peace and comfort in the life of bermayarakat. Because religions have taught the truth and goodness and distanced from all malice, strife, discrimination etc. Religious life looks on mindset, behaviour or attitude and way of living one's religious attitude embodiment and able to receive different neighbor any religion as a servant of God Almighty. Religion as a guide of human life created by God, the one true God through his life. Whereas culture is as a habit or an Ordinance of human life created by the man itself results from creativity, taste and karsanya given by the Lord. Religion and culture influence each other each other. Religion affects culture, community groups, and ethnic groups. The culture tends to be fickle to any people or groups who really lives in accordance with the mandate his religion each, hence will automatically be eventuate harmony, the peace and comfort in life bermayarakat. Because of religion have taught truth and goodness and removed from all philippic, dissensions, discrimination and others. Religious life looks on people think, behavior or attitude and manner embodiment attitude religious life someone and capable of receiving fellow different any religious as the servants of allah swt. Religion as a guideline human life created by god, of almighty god in lived his life. While culture is as habit or procedures of human life created by human beings themselves from the power copyright, taste and karsanya given by god. Religion and culture interplay each other. Religious affect culture, the group, and peoples. Culture capricious tending to any people or groups who really lives in accordance with each, amanah his religion hence with itself would be harmony, the fraternity, peace and comfort in life community. Because of religion have taught truth and goodness and badness, taking away from all dissensions, discrimination and others. Religious life seemed in a pattern of thought, of behavior or attitude and manner of living religious embodiment of the attitude of someone and capable of receiving a fellow who is different any religious a follower of allah swt. Religion as a guideline human life created by the lord of almighty god in lived his life. While culture is as the habit or procedures of human life created by human beings themselves from the power of copyright, taste and karsanya given by god. Religion and culture on each other. Affecting culture, religion community groups, and peoples.
\end{abstract}

Keywords :Religion, cultural and society

\section{PENDAHULUAN}

Fenomena kehidupan masyarakat dilihat dari aspek agama dan budaya yang memiliki keterkaitan satu sama lain yang terkadang banyak disalah artikan oleh sebagian orang yang belum memahami 
bagaimana menempatkan posisi agama dan posisi budaya dalam suatu kehidupan masyarakat. Dalam kehidupan manusia, agama dan budaya jelas tidak berdiri sendiri, keduanya memiliki hubungan yang sangat erat dalam dialektikanya; selaras menciptakan dan kemudian saling menegasikan. Agama sebagai pedoman hidup manusia yang diciptakan oleh Tuhan, dalam menjalani kehidupannya. Sedangkan kebudayaan adalah sebagai kebiasaan tata cara hidup manusia yang diciptakan oleh manusia itu sendiri dari hasil daya cipta, rasa dan karsanya yang diberikan oleh Tuhan. Agama dan kebudayaan saling mempengaruhi satu sama lain. Agama mempengaruhi kebudayaan, kelompok masyarakat, dan suku bangsa. Kebudayaan cenderung berubah-ubah yang berimplikasi pada keaslian agama sehingga menghasilkan penafsiran berlainan. Salah satu agenda besar dalam kehidupan masyarakat, berbangsa dan bernegara adalah menjaga persatuan dan kesatuan dan membangun kesejahteraan hidup bersama seluruh warga negara dan umat beragama. Hambatan yang cukup berat untuk mewujudkan kearah keutuhan dan kesejahteraan adalah masalah kerukunan sosial, termasuk di dalamnya hubungan antara agama dan kerukunan hidup umat beragama. Persoalan ini semakin kursial karena terdapat serangkaian kondisi sosial yang menyuburkan konflik, sehingga terganggu kebersamaan dalam membangun keadaan yang lebih dinamis dan kondusif. Demikian pula kebanggaan terhadap kerukunan dirasakan selama bertahun-tahun mengalami degradasi, bahkan menimbulkan kecemasan terjadinya disintegrasi bangsa.

Latar belakang lahirnya agama karena adanya masalah kekuatan yang dianggap lebih tinggi dari kekuatan yang ada pada dirinya sehingga mereka mencari lebih dalam dari mana asal kekuatan yang ada pada alam baik berupa gunung laut langit dan sebagainya, dan ketika mereka tidak dapat mengkajinya maka disembah karena mereka berpikiran, bahwa kekuatan alam itu memiliki kekuatan yang luar biasa dan bisa menghidupi beribu-ribu, bahkan berjuta-juta umat manusia sehingga muncullah agama yang merupakan salah satu usaha manusia untuk mendekatkan diri pada kekuatan supranatural.

Sebelum kita memahami perspektif agama, budaya dan masyarakat, maka terlebih dahulu kita harus mengetahui penjelasan eksistensi tentang agama. Agama merupakan suatu kepercayaan tertentu yang dianut sebagian besar masyarakat merupakan tuntunan hidup. Agama menyangkut kepercayaan-kepercayaan dan berbagai prakteknya, serta benar-benar merupakan masalah sosial yang pada saat ini senantiasa ditemukan dalam setiap masyarakat manusia. Karena itu, lahir pertanyaan bagaimana seharusnya dari sudut pandang sosiologis. Dalam pandangan sosiologi, perhatian utama agama adalah pada fungsinya bagi masyarakat. Di mana fungsi seperti diketahui, menunjuk pada sumbangan yang diberikan agama atau lembaga sosial yang lain untuk memper-tahankan keutuhan masyarakat sebagai usaha aktif yang berlangsung secar terus-menerus.

Konsepsi agama menurut kamus besar bahasa indonesia adalah sistem yang mengatur tata keimanan (kepercayaan) dan peribadatan kepada tuhan yang mahakuasa serta tata kaidah yang. Menurut Yusuf Alqaradawi dan Hussein Shahatah, zakat gaji dan pendapatan diistilahkan sebagai zakat mal almustafad yaitu zakat yang bersumberkan gaji. Agama dengan agama hidup itu terarah, dengan seni hidup itu indah, dengan ilmu hidup itu mudah ilmu tanpa agama adalah buta, agama tanpa ilmu adalah lumpuh pengertian lembaga agama.

Penulis masih sering menyaksikan adanya sebahagian anggota masyarakat yang mencampur adukkan antara nilai-nilai agama dengan nilai-nilai budaya yang padahal kedua hal tersebut tentu saja tidak dapat seratus persen disamakan, bahkan mungkin berlawanan. Demi terjaganya esistensi dan kesucian nilai-nilai agama sekaligus memberi pengertian, disini penulis hendak mengulas mengenai Apa itu agama dan apa itu budaya, dan masyarakat yang memiliki hubungan yang kuat. 
Budaya atau yang biasa di sebut culture merupakan warisan dari dari nenek moyang terdahlu yang masih eksis sampai saat ini. Suatu bangsa tidak akan memiliki ciri khas tersendiri tanpa adanya budaya-budaya yang di miliki. Budaya-budaya itupun berkembang sesui dengan kemajuan zaman yang semakin modern. Kebudayaan yang berkembang dalam suatu bangsa itu sendiri di namakan dengan kebudayaan lokal, karena kebudayaan lokal sendiri merupakan sebuah hasil cipta, karsa dan rasa yang tumbuh dan berkembang di dalam suku bangsa yang ada di daerah tersebut. Di dalam kebudayaan suatu pasti menganut suatu kepercayaan yang bisa kita sebut dengan agama. Agama itu sendiri iyalah sistem atau prinsip kepercayaan kepada Tuhan atau juga disebut dengan nama Dewa atau nama lainnya dengan ajaran kebhaktian dan kewajiban yang bertalian dengan kepercayaan yang dianut oleh suatu suku/etnik tersebut.

Rumusan masalahnya adalah sebagai berikut: 1) Bagaimana perbedaan konsep agama, budaya dan masyarakat? 2) Bagaimana perspektif agama, kebudayaa dan masyarakat di Indonesia? 3) Mengapa manusia sebagai pencipta dan pengguna kebudayaan? 4) Bagaimana peranan dan hubungan kebudayaan dengan agama dalam masyarakat? 5) Bagaimana pengaruh agama Islam dalam kehidupan masyarakat Indonesia?

\section{METODE PENELITIAN}

Metode penelitian yang digunakan adalah deskriptif kualitatif dengan pendekatan fenomenologi. Pendekatan fenomenologi mencoba menjelaskan atau mengungkap makna konsep atau fenomena pengalaman yang didasari oleh kesadaran yang terjadi pada beberapa individu. Penelitian ini dilakukan dalam situasi yang alami, sehingga tidak ada batasan dalam memaknai atau memahami fenomena yang dikaji. Creswell (1998:54) mengatakan bahwa, pendekatan fenomenologi menunda semua penilaian tentang sikap yang alami sampai ditemukan dasar tertentu. Penundaan ini biasa disebut epoche (jangka waktu).
Konsep epoche adalah membedakan wilayah data (subjek) dengan interpretasi peneliti. Konsep epoche menjadi pusat dimana peneliti menyusun dan mengelompokkan dugaan awal tentang fenomena untuk mengerti tentang apa yang dikatakan oleh responden.

Selanjutnya, peneliti melakukan analisis data yang merupakan upaya mencari dan menata secara sistematis catatan hasil observasi, wawancara, dan lainnya untuk meningkatkan pemahaman peneliti tentang kasus yang diteliti dan menyajikannya sebagai temuan kepada orang lain. Adapun untuk meningkatkan pemahaman tersebut analisis perlu dilanjutkan dengan berupaya mencari makna (meaning) (Muhadjir,2002 :142).

Analisis data dengan model Miles dan Huberman, di mana proses mencari dan menyusun secara sistematis data yang diperoleh dari hasil wawancara, catatan lapangan dan dokumentasi, dengan cara mengorganisaikan data ke dalam kategori, menjabarkan ke dalam unit-unit, melakukan sintesa, menyusun kedalam pola, memeilih mana yang penting dan akan dipelajari, serta membuat kesimpulan sehingga mudah dipahami oleh diri sendiri dan orang lain. Analisis data kualitatif adalah bersifat induktif, yaitu suatu analisis berdasarkan data yang diperoleh, selanjutnya dikembangkan menjadi hipoteisis. Berdasarkan hipotesis yang dirumuskan berdasarkan data tersebut, selanjutnya dicarikan data lagi secara berulang, sehingga dapat disimpulkan apakah hipotesis tersebut diterima atau ditolak berdasarkan data yang terkumpul. Bila berdasarkan data yang dapat dikumpulkan secara berulang-ulang dengan teknik triangulasi, ternyata hipotesis diterima, maka hipotesis tersebut berkembang menjadi teori.

Selain itu, analisis data dalam penelitian kualitatif, dilakukan pada saat pengumpulan data berlangsung, dan setelah selesai pengunpulan data dalam periode tertentu. Pada saat wawancara, peneliti sudah melakukan analisis terhadap jawaban yang diwawencarai. Bila jawaban yang diwawancarai setelah dianalisis terasa belum 
memuaskan, maka peneiiti akan melanjutkan pertanyaan lagi, sampai tahap tertentu, diperoleh data yang dianggap kredibel. Miles dan Huberman (1984), mengemukakan bahwa aktivitas dalam analisis data kualitatif dilakukan secara interaktif dan berlangsung secara terus menerus sampai tuntas, sehingga datanya sudah jenuh. Aktivitas dalam analisis data, yaitu data reduction, data display, dan conclusion drawing/verification.

Kemudian peneliti melakukan reduksi data yang diperoleh dari lapangan yang jumlahnya cukup banyak, untuk itu maka perlu dicatat secara teliti dan rinci. Seperti telah dikemukakan, semakin lama peneliti ke lapangan, maka jumlah data akan semakin banyak, kompleks dan rumit, untuk itu perlu segera dilakukan analisis data melalui reduksi data. Mereduksi data berarti merangkum, memilih hal-hal yang pokok, memfokuskan pada hal-hal yang penting, dicari tema dan polanya.

Data yang telah direduksi akan memberikan gambaran yang lebih jelas dan mempermudah peneliti untuk melakukan pengumpulan data selanjutnya, dan mencarinya bila diperlukan. Reduksi data dapat dibantu dengan peralatan elektronik seperti komputer mini dengan memberikan kode pada aspek-aspek tertentu. Selain itu pada situasi sosial tertentu, peneliti dalam mereduksi data mungkin akan memfokuskan pada orang miskin, pekerjaan sehari-hari yang dikerjakan, dan rumah tinggalnya. Sedangkan dalam bidang manajemen reduksi data peneliti akan memfokuskan pada bidang pengawasan, dengan melihat perilaku orang-orang yang jadi pengawas, metode kerja, tempat kerja, interaksi antara pengawas dengan yang diawasi, serta hasil pengawasan.

\section{HASIL DAN PEMBAHASAN Konsepsi, Hubungan Agama, Kebuda- yaan dan Masyarakat}

Sejak awal perkembangannya, agamaagama di Indonesia telah menerima akomodasi budaya. Sebagai contoh Agama Islam, dimana Islam sebagai agama faktual banyak memberikan norma-norma atau aturan tentang kehidupan dibandingkan dengan agama-agama lain. Jika dilihat dari kaitan Islam dengan budaya, paling tidak ada dua hal yang perlu diperjelas. Pertama, Islam sebagai konsespsi sosial budaya dan Islam sebagai realitas budaya. Kedua, Islam sebagai konsepsi budaya ini oleh para ahli sering disebut dengan great tradition (tradisi besar), sedangkan Islam sebagai realitas budaya disebut dengan little tradition (tradisi kecil) atau local tradition (tradisi local) atau juga Islamicate, bidang-bidang yang "Islamik" yang dipengaruhi Islam.

Tradisi besar Islam adalah doktrindoktrin original Islam yang permanen atau setidak-tidaknya merupakan interpretasi yang melekat ketat pada ajaran dasar. Dalam ruang yang lebih kecil doktrin ini tercakup dalam konsepsi keimanan dan syariah atau hukum Islam yang menjadi inspirasi pola pikir dan pola bertindak umat Islam. Tradisitradisi ini seringkali juga disebut dengan center (pusat) yang dikontraskan dengan feri-feri atau pinggiran.

Tradisi kecil (local, Islamicate traditioan) adalah realm of influence, kawasankawasan yang berada di bawah pengaruh Islam (great tradition). Tradisi lokal ini mencakup unsur-unsur yang terkandung di dalam pengertian budaya yang meliputi konsep atau norma, aktivitas serta tindakan manusia, dan berupa karya-karya yang dihasilkan masyarakat. Istilah lain, proses akulturasi antara agama Islam dan budaya lokal ini kemudian melahirkan apa yang dikenal dengan local genius, yaitu kemampuan menyerap sambil mengadakan seleksi dan pengolahan aktif terhadap pengaruh kebudayaan asing, sehingga dapat dicapai suatu ciptaan baru yang unik, yang tidak terdapat di wilayah bangsa yang membawa pengaruh budayanya. Pada sisi lain local genius memiliki karakteristik antara lain: mampu bertahan terhadap budaya luar; mempunyai kemampuan mengakomodasi unsur-unsur budaya luar; mempunyai kemampuan mengintegrasi unsur budaya luar ke dalam budaya asli; dan memiliki kemampuan mengendalikan dan 
memberikan arah pada perkembangan budaya selanjutnya. Sebagai suatu norma, aturan, maupun segenap aktivitas masyarakat Indonesia, ajaran Islam telah menjadi pola anutan masyarakat. Dalam konteks inilah Islam sebagai agama sekaligus telah menjadi budaya masyarakat Indonesia. Di sisi lain budaya-budaya lokal yang ada di masyarakat, tidak otomatis hilang dengan kehadiran Islam. Budaya-budaya lokal ini sebagian terus dikembangkan dengan mendapat warna-warna Islam. Perkembangan ini kemudian melahirkan "akulturasi budaya", antara budaya lokal dan Islam.

Budaya-budaya lokal yang kemudian berakulturasi dengan Agama Islam antara lain, acara slametan $(3,7,40,100$, dan 1000 hari) di kalangan suku Jawa. Tingkeban (nujuh hari). Dalam bidang seni, juga dijumpai proses akulturasi seperti dalam kesenian wayang di Jawa. Wayang merupakan kesenian tradisional suku/etnis Jawa yang berasal dari agama Hindu India. Proses Islamisasi tidak menghapuskan kesenian ini melainkan justru memperkayanya, yaitu memberikan warna nilai-nilai Islam di dalamnya.tidak hanya dalam bidang seni, tetapi juga di dalam bidang-bidang lain di dalam masyarakat Jawa. Dengan kata lain kedatangan Islam di Indonesia dalam taraftaraf tertentu memberikan andil yang cukup besar dalam pengembangan budaya lokal.

Pada sisi lain, secara fisik akulturasi budaya yang bersifat material dapat dilihat misalnya: bentuk masjid Agung Banten yang beratap tumpang, berbatu tebal, bertiang saka, dan sebagainya benar-benar menunjukkan ciri-ciri arsitektur local. Sementara esensi Islam terletak pada "ruh" fungsi masjidnya. Demikian juga dua jenis pintu gerbang bentar dan paduraksa sebagai ambang masuk masjid di Keraton Kaibon. Namun sebaliknya, "wajah asing" pun tampak sangat jelas di kompleks Masjid Agung Banten, yakni melalui pendirian bangunan Tiamah dikaitkan dengan arsitektur buronan Portugis,Lucazs Cardeel, dan pendirian menara berbentuk mercu suar dihubungkan dengan nama seorang Cina: Cek-ban Cut.
Dalam perkembangan selanjutnya sebagaimana diceritakan dalam Babad Banten, Banten kemudian berkembang menjadi sebuah kota. Kraton Banten sendiri dilengkapi dengan struktur-struktur yang mencirikan prototype kraton yang bercorak Islam di Jawa, sebagaimana di Cirebon, Yogyakarta dan Surakarta. Ibukota Kerajaan Banten dan Cirebon kemudian berperan sebagai pusat kegiatan perdagangan internasional dengan ciri-ciri metropolitan di mana penduduk kota tidak hanya terdiri dari penduduk setempat, tetapi juga terdapat perkampungan-perkampunan orang-orang asing, antara lain Pakoja, Pecinan, dan kampung untuk orang Eropa seperti Inggris, Perancis dan sebagainya.

Dalam bidang kerukunan, Islam di daerah Banten pada masa lalu tetap memberikan perlakuan yang sama terhadap umat beragama lain. Para penguasa muslim di Banten misalnya telah memperlihatkan sikap toleransi yang besar kepada penganut agama lain. Misalnya dengan mengizinkan pendirian vihara dan gereja di sekitar pemukiman Cina dan Eropa. Bahkan adanya resimen non-muslim yang ikut mengawal penguasa Banten. Penghargaan atau perlakuan yang baik tanpa membeda-bedakan latar belakang agama oleh penguasa dan masyarakat Banten terhadap umat beragama lain pada masa itu, juga dapat dilisaksikan di kawasan-kawasan lain di nusantara, terutama dalam aspek perdagangan. Penguasa Islam di berbagai belahan nusantara telah menjalin hubungan dagang dengan bangsa Cina, India dan lain sebagainya sekalipun di antara mereka berbeda keyakinan. Aspek akulturasi budaya lokal dengan Islam juga dapat dilihat dalam budaya Sunda adalah dalam bidang seni vokal yang disebut seni beluk. Dalam seni beluk sering dibacakan jenis cirita (wawacan) tentang ketauladanan dan sikap keagamaan yang tinggi dari yang ditokohkan.

Seringkali wawacan dari seni beluk ini berasal dari unsur budaya local pra-Islam kemudian dipadukan dengan unsur Islam seperti pada wawacan Ugin yang mengisahkan manusia yang memiliki kualitas 
kepribadian yang tinggi. Seni beluk kini biasa disajikan pada acara-acara selamatan atau tasyakuran, misalnya memperingati kelahiran bayi ke-4- hari (cukuran), upacara selamatan syukuran lainnnya seperti kehamilan ke-7 bulan (nujuh bulan atau tingkeban), khitanan, selesai panen padi dan peringatan hari-hari besar nasional.

Akulturasi budaya Islam dengan budaya lokal nusantara sebagaimana yang terjadi di Jawa didapati juga di daerah-daearah lain di luar Jawa, seperti Sumatera Barat, Aceh, Makasar, Kalimantan, Sumatera Utara, dan daerah-daerah lainnya. Khusus di daerah Sumatera Utara, proses akulurasi ini antara lain dapat dilihat dalam acara-acara seperti upah-upah, tepung tawar, dan Marpangir. Apabila ditinjau dari segi munculnya, agama-agama selain monoteisme murni merupakan hasil kontemplasi manusia, sedangkan monoteisme murni merupakan wahyu dari hasil ciptaan Tuhan. Ragam agama yang terakhir ini merupakan jawaban dari pertolongan Tuhan terhadap manusia setelah "gagal" mencari kedamaian atau kedamaian hakiki melalui indera.

Bila kita amati secara obyektif, Islam memiliki ciri-ciri baik dalam konsep Ketuhanan, Kerasulan dan ajaran-ajaran yang menunjukkan kesatuan (Tauhid) yang murni. Syarat mencapai suatu kebenaran dan kedamaian yang sebenarnya haruslah terlebih dahulu mengenal Islam dengan tepat dan benar. Kemudian harus komitmen terhadap ajarannya.

Terwujudnya suatu "kedamaian" apabila didukung dengan adanya penyerahan serta kepatuhan (Islam) terhadap Sang Pencipta. Dalam hal ini Allah SWT telah telah berjanji kepada siapa pun yang menyerahkan diri disertai amal sholeh, akan mendapatkan kedamaian, sebab dalam penyerahan (Islam) ini terdapat konsekuensi sikap muslim yang logis, tidak pernah gentar, pesimis dan takut dalam hidupnya.

Al-Qur'an mempergunakan kata Islam di berbagai tempat dengan pengertian yang berbeda-beda, namun pada prinsipnya mengarah pada pemahaman yang sama. Pengertian Islam secara umum yakni mengandung dimensi iman yang tidak dikotori oleh unsur-unsur syirik, tunduk, disertai dengan rasa ikhlas karena Allah SWT, berserah diri diiringi dengan amal sholeh serta sikap tegar dan optimis. Jadi pengertian Islam secara lughowi pada prinsipnya merupakan penyerahan diri secara bulat kepada Allah SWT yang melahirkan satu sikap hidup tertentu.

Para orientalis menyebut "Islam" dengan istilah "Muhammadanisme". Mereka mengasosiakan sebutan ini dengan sebutansebutan bagi agama-agama selain Islam yang dianalogikan pada pembawanya atau tempat kelahirannya. Agama Nasrani diambil dari negeri kelahirannya (Nazaret). Kristen diambil dari nama pembawanya (Yesus Kristus). Budha (Budhisme) dari nama pembawanya (Sang Budha Gautama), Zoroaster (Zoroasteranisme) dari pendirinya, Yahudi (Yuda-isme) dari negerinya (Yudea).

Namun, nam Islam mengandung pengertian yang mendasar. Agama Islam bukanlah milik pembawanya yang bersifat individual atau pun diperuntukkan bagi suatu golongan atau negara tertentu. Islam sebagai agama universal dan eternal merupakan wujud realisasi dari konsep Rahmatan Lil Alamin (rahmat bagi seluruh umat). Istilah "Muhammadanisme" membuka peluang bagi timbulnya berbagai interpretasi serta persepsi terhadap Islam yang diidentikkan dengan agama-agama lain yang jelas berbeda konsep.

Sejak awal sejarah lahirnya manusia, terdapat satu bentuk petunjuk yang berupa wahyu ilahi melalui seorang Rosul (agama Allah). Agama-agama Allah tersebut pada prinsipnya merupakan agama-agama yang yang menyerahkan diri hanya kepada Tuhan Yang Satu. Mengenai konsep Tuhan Yang Satu dan ajaran penyerahan diri kepada Allah SWT, tetaplah sama. Hubungan semua Rosul sejak Adam A.S. sampai Muhammad SAW., berdasarkan ajaran yang mereka bawakan, bagaikan mata rantai yang selalu datang berkesinambungan dan merupakan penyempurnaan ajaran sebelumnya sehingga agama Allah tersebut akan 
mampu menjawab seluruh hajat manusia di berbagai zaman, kapan dan dimana saja.

Konsep budaya atau kebudayaan berasal dari bahasa Sanskerta yaitu buddhayah, yang merupakan bentuk jamak dari buddhi (budi atau akal), diartikan sebagai hal-hal yang berkaitan dengan budi dan akal manusia. Dalam bahasa Inggris, kebudayaan disebut culture, yang berasal dari kata Latin colere, yaitu mengolah atau mengerjakan. Bisa diartikan juga sebagai mengolah tanah atau bertani. Kata culture juga kadang diterjemahkan sebagai "kultur" dalam bahasa Indonesia. Kemudian pengertian ini berkembang dalam arti culture, yaitu sebagai sebagai daya dan aktivitas manusia untuk mengolah dan mengubah alam. Berikut pengertian budaya atau kebudaan menurut beberapa ahli :

- E. B. Tylor, budaya adalah suatu keluruhan yang kompleks yang meliputi pengetahuan, kepercayaan, kesenian, moral, keilmuan, hukum, adat istiadat, dan kemampuan yang lain sera kebiasaan yang didapat oleh manusia sebagai anggota masyarakat.

- R. Linton, kebudayaan dapat dipandang sebagai konfigurasi tingkah yang dipelajari dan hasil tingkah laku yang dipelajari, dimana unsur pembentuknya didukung dan diteruskan oleh angota masyarakat lainnya.

- Koentjaraningrat, kebudayaan iyalah seluruh sistem gagasan milik manusia dengan belajar.

- Selo Soemardjan dan Soelaeman Soemardi, menyatakan bahwa kebudayaan adalah semua hasil karya, rasa, dan cipta masyarakat.

- Herkovits, kebudayaan adalah bagian dari lingkungan hidup yang dicintai manusia.

Dengan demikian kebudayaan atau budaya menyangkut seluruh aspek kehidupan manusia baik material maupun non material. Sebagian besar ahli yang mengartikan kebudayaan kemungkinan besar sangat di pengaruhi oleh pandangan evolusionisme, yaitu suatu teori yang mengatakan bahwa kebudayaan itu akan berkembang dari tahapan yang sederhana menuju tahapan yang lebih kompleks.

Konsep masyarakat adalah suatu sistem sosial yang menghasilkan kebudayaan (Soerjono Soekanto, 1983). Sedangkan agama menurut Kamus Besar Bahasa Indonesia adalah sistem atau prinsip kepercayaan kepada Tuhan, atau juga disebut dengan nama Dewa atau nama lainnya dengan ajaran kebaktian dan kewajiban-kewajiban yang berkaitan dengan kepercayaan tersebut. Sedangkan Agama di Indonesia memegang peranan penting dalam kehidupan masyarakat. Hal ini dinyatakan dalam ideologi bangsa Indonesia, Pancasila: "Ketuhanan Yang Maha Esa".

Sejumlah agama di Indonesia berpengaruh secara kolektif terhadap politik, ekonomi dan budaya. Di tahun 2000, kirakira $86,1 \%$ dari 240.271 .522 penduduk Indonesia adalah pemeluk Islam, 5,7\% Protestan, 3\% Katolik, 1,8\% Hindu, dan $3,4 \%$ kepercayaan lainnya. Secara normatif dalam UUD 1945 dinyatakan bahwa "tiap-tiap penduduk diberikan kebebasan untuk memilih dan mempraktekkan kepercayaannya" dan "menjamin semuanya akan kebebasan untuk menyembah, menurut agama atau kepercayaannya". Pemerintah bagaimanapun, secara resmi hanya mengakui enam agama, yakni Islam, Protestan, Katolik, Hindu, Buddha, dan Konghucu. Banyaknya agama maupun aliran kepercayaan yang ada di Indonesia, konflik antar agama sering kali tidak terelakkan. Lebih dari itu, kepemimpinan politis Indonesia memainkan peranan penting dalam hubungan antar kelompok maupun golongan. Program transmigrasi secara tidak langsung telah menyebabkan sejumlah konflik di wilayah Timur Indonesia.

Menurut sejarah, kaum pendatang telah menjadi pendorong utama keanekaragaman agama dan kultur di dalam negeri dengan pendatang dari India, Tiongkok, Portugal, Arab, dan Belanda. Bagaimanapun, hal ini sudah berubah sejak beberapa perubahan telah dibuat untuk menyesuaikan kultur di Indonesia. 
Berdasarkan uraian di atas, Penetapan Presiden No 1 Tahun 1965 Tentang Pencegahan Penyalahgunaan dan/atau Penodaan Agama pasal 1, "Agama-agama yang dipeluk oleh penduduk di Indonesia ialah Islam, Kristen, Katolik, Hindu, Budha dan Khong $\mathrm{Hu} \mathrm{Cu}$ (Confusius)".

- Islam : Indonesia merupakan negara dengan penduduk Muslim terbanyak di dunia, dengan $88 \%$ dari jumlah penduduk adalah penganut ajaran Islam. Mayoritas Muslim dapat dijumpai di wilayah barat Indonesia seperti di Jawa dan Sumatera. Masuknya agama Islam ke Indonesia melalui perdagangan.

- Hindu : Kebudayaan dan agama Hindu tiba di Indonesia pada abad pertama Masehi, bersamaan waktunya dengan kedatangan agama Buddha, yang kemudian menghasilkan sejumlah kerajaan Hindu-Buddha seperti Kutai, Mataram dan Majapahit.

- Budha : Buddha merupakan agama tertua kedua di Indonesia, tiba pada sekitar abad keenam masehi. Sejarah Buddha di Indonesia berhubungan erat dengan sejarah Hindu.

- Kristen Katolik : Agama Katolik untuk pertama kalinya masuk ke Indonesia pada bagian pertama abad ketujuh di Sumatera Utara. Dan pada abad ke-14 dan ke-15 telah ada umat Katolik di Sumatera Selatan. Kristen Katolik tiba di Indonesia saat kedatangan bangsa Portugis, yang kemudian diikuti bangsa Spanyol yang berdagang rempah-rempah.

- Kristen Protestan : Kristen Protestan berkembang di Indonesia selama masa kolonial Belanda (VOC), sekitar abad ke16. Kebijakan VOC yang mengutuk paham Katolik dengan sukses berhasil meningkatkan jumlah penganut paham Protestan di Indonesia. Agama ini berkembang pesat di abad ke-20, yang ditandai oleh kedatangan para misionaris dari Eopa ke beberapa wilayah di Indonesia, seperti di wilayah barat Papua dan lebih sedikit di kepulauan Sunda.

- Konghucu : berasal dari Cina daratan dan yang dibawa oleh para pedagang
Tionghoa dan imigran. Diperkirakan pada abad ketiga Masehi, orang Tionghoa tiba di kepulauan Nusantara. Berbeda dengan agama yang lain, Konghucu lebih menitik beratkan pada kepercayaan dan praktik yang individual.

\section{Manusia Sebagai Pencipta dan Pengguna Kebudayaan}

Budaya merupakan hasil dari interaksi antara manusia dengan segala isi yang ada di alam raya ini. Manusia di ciptakan oleh tuhan dengan di bekali oleh akal pikirannya sehingga dia mampu untuk berkarya di muka bumi ini dan secara hakikatnya menjadi khalifah di muka bumi ini (dalam Rafael Raga Maran, 1999:36). Selain itu manusia juga memiliki akal, intelegensiai, perasaan, emosi, keinginan, dan perilaku.

Semua kemampuan yang dimiliki oleh manusia maka manusia mampu menciptakan suatu kebudayaan. Ada hubungan antara manusia dan kebudayaan. Kebudayaan adalah produk manusia, namun manusia itu sendiri adalah produk kebudayaan. Dengan kata lain, kebudayaan ada karena manusialah yang menciptakan dan manusia dapat hidup di tengah kebudayaan yang telah diciptakannya. Kebudayaan akan terus berjalan manakala ada manusia sebagai pendudukungnya.

Kebudayaan mempunyai kegunaan sangat besar bagi manusia. Hasil karya manusia menimbulkan teknologi yang mempunyai kegunaan utama dalam melindungi manusia terhadap lingkungan alamnya. Sehingga kebudayaan memiliki peran sebagai berikut :

1) Suatu hubungan pedoman antarmanusia atau kelompoknya

2) Wadah untuk menyalurkan perasaan dan kemampuan-kemampuan lain.

3) Sebagai pembimbing kehidupan dan penghidupan manusia

4) Pembeda manusia dan binatang

5) Petunjuk-petunjuk tentang bagaimana manusia harus bertindak dan berprilaku di dalam pergaulan.

6) Pengatur agar manusia dapat mengerti bagaimana seharusnya bertindak, berbuat 
7) Sebagai modal dasar pembangunan.

Manusia merupkan makhluk yang berbudaya, melalui akalnya manusia dapat mengembangkan kebudayaan, begitupula manusia hidup dan bergantung pada kebudayaan sebagai hasil ciptaannya. Kebudayaan juga memberikan aturan bagi manusiadalam mengelolah lingkungan dengan teknologi hasil ciptaannya. Berbagai macam kekuatan manusia harus menhadapi kekuatan alam dan kekuata-kekuatan yang lain. Selain itu manusia memerlukan kepuasan yang baik secara sipiritual maupun material.

Kebudayaan masyarakat sebagian besar dipengaruhi oleh kebudayaan yang bersumber dari masyarakat itu sendiri. Hasil karya masyarakat itu sendiri melahirkan teknologi atau kebuyaan kebendaan yang memiliki kegunaan utama dalam melindungi diri mereka sendiri terhadap lingkungan. Dalam tindakan untuk melindungi diri dari lingkungan alam, pada taraf pemula manusia bersikap menyerah dan semata-mata bertindak didalam batas-batas untuk melindungi dirinya. Keadaan berbeda pada masyarakat yang kompleks, dimana taraf kebudayaannya lebih tinggi. Hasil karya tersebut yaitu teknologi yang memberikan kemungkinan luas untuk memanfaatkan hasil alam bahkan menguasai alam.

\section{Hubungan Agama dan Kebudayaan dalam Masyarakat}

Kebudayaan tampil sebagai perantara yang secara terus menerus dipelihara oleh para pembentuknya dan generasi selanjutnya yang diwarisi kebudayaan tersebut. Kebudayaan yang demikian selanjutnya dapat pula digunakan ntuk memahami agama yang terdapat pada dataran empiriknya atau agama yang tampil dalam bentuk formal yang menggejala di masyarakat. Pengalaman agama yang terdapat di masyarakat tersebut diproses oleh penganutnya dari sumber agama yaitu wahyu melalui penalaran. Misalnya kita membaca kitab fikih, maka fikih yang merupakan pelaksanaan dari nash Al-Qur'an maupun hadist sudah melibatkan unsur penalaran dan kemampuan manusia. Dengan demikian agama menjadi membudaya atau membumi di tengah-tengah masyarakat. Agama yang tampil dalam bentuknya yang demikian itu berkaitan dengan kebudayaan yang berkembang di masyarakat tempat agama itu berkembang. Dengan melalui pemahaman terhadap kebudayaan tersebut seseorang akan dapat mengamalkan ajaran agama. Misalnya manusia menjumpai kebudayaan berpakaian, bergaul bermasyarakat, dan sebagainya. Ke dalam produk kebudayaan tersebut unsur agama ikut berintegrasi. Dalam pakaian model jilbab, kebaya atau lainnya dapat dijumpai dalam pengalaman agama. Sebaliknya tanpa adanya unsur budaya, maka agama akan sulit dilihat sosoknya secara jelas.

Selain itu hubungan agama dan kebudayaan dalam konteks budaya Indonesia, maka budaya itu terdiri dari 5 lapisan. Lapisan itu diwakili oleh budaya agama pribumi, Hindu, Buddha, Islam dan Kristen (Andito, ed. 1998:77-79) Lapisan pertama adalah agama pribumi yang memiliki ritusritus yang berkaitan dengan penyembahan roh nenek moyang yang telah tiada atau lebih setingkat yaitu Dewa-dewa suku seperti sombaon di Tanah Batak, agama Merapu di Sumba, Kaharingan di Kalimantan. Dari agama pribumi bangsa Indonesia mewarisi kesenian dan estetika yang tinggi dan nilai-nilai kekeluargaan yang sangat luhur. Lapisan kedua dalah Hinduisme, yang telah meninggalkan peradaban yang menekankan pembebasan rohani agar atman bersatu dengan Brahman maka dengan itu ada solidaritas mencari pembebasan bersama dari penindasan sosial untuk menuju kesejahteraan yang utuh. Lapisan ketiga adaalah agama Buddha, yang telah mewariskan nilai-nilai yang menjauhi ketamakan dan keserakahan. Bersama dengan itu timbul nilai pengendalian diri dan mawas diridengan menjalani 8 tata jalan keutamaan. Lapisan keempat adalah agama Islam yang telah menyumbangkan kepekaan terhadap tata tertib kehidupan melalui syari'ah, ketaatan melakukan shalat dalam lima waktu,kepekaan terhadap mana yang 
baik dan mana yang jahat dan melakukan yang baik dan menjauhi yang jahat (amar ma'ruf nahi munkar) berdampak pada pertumbuhan akhlak yang mulia. Inilah halhal yang disumbangkan Islam dalam pembentukan budaya bangsa. Lapisan kelima adalah agama Kristen, baik Katholik maupun Protestan. Agama ini menekankan nilai kasih dalam hubungan antar manusia. Tuntutan kasih yang dikemukakan melebihi arti kasih dalam kebudayaan sebab kasih ini tidak menuntutbalasan yaitu kasih tanpa syarat. Kasih bukan suatu cetusan emosional tapi sebagai tindakan konkrit yaitu memperlakukan sesama seperti diri sendiri. Dipandang dari segi budaya, semua kelompok agama di Indonesia telah mengembangkan budaya agama untuk mensejahterakannya tanpa memandang perbedaan agama, suku dan ras.

Disamping pengembangan budaya immaterial tersebut agama-agama juga telah berhasil mengembangkan budaya material seperti candi-candi dan bihara-bihara di Jawa tengah, sebagai peninggalan budaya Hindu dan Buddha, sedang budaya Islam antara lain telah mewariskan Masjid Agung Demak (1428) di Gelagah Wangi Jawa Tengah. Masjid ini beratap tiga susun yang khas Indonesia, berbeda dengan masjid Arab umumnya yang beratap landai. Atap tiga susun itu menyimbolkan Iman, Islam dan Ihsan. Masjid ini tanpa kubah, benar-benar has Indonesia yang mengutamakan keselarasan dengan alam.Masjid Al-Aqsa Menara Kudus di Banten bermenaar dalam bentuk perpaduan antara Islam dan Hindu. Masjid Rao-rao di Batu Sangkar merupakan perpaduan berbagai corak kesenian dengan hiasan-hiasan mendekati gaya India sedang atapnya dibuat dengan motif rumah Minangkabau (Philipus Tule 1994:159). Kenyataan adanya tersebut membuktikan bahwa agama-agama di Indonesia telah membuat manusia makin berbudaya sedang budaya adalah usaha manusia untuk menjadi manusia.

Pengaruh timbal balik antara agama dan budaya : 1) Agama mempengaruhi kebudayaan, kelompok, masyarakat, dan suku bangsa; 2) Kebudayaan cenderung mengubah-ubah keaslian agama seshingga menghasilkan penafsiran berlainan.

Hal pokok bagi semua agama adalah bahwa agama berfungsi sebagai alat pengatur dan sekaligus membudayakannya dalam arti mengungkapkan apa yang ia percaya dalam bentuk-bentuk budaya yaitu dalam bentuk etis, seni bangunan, struktur masyarakat, adat istiadat dan lain-lain. Jadi ada pluraisme budaya berdasarkan kriteria agama. Hal ini terjadi karena manusia sebagai homoreligiosus merupakan insan yang berbudidaya dan dapat berkreasi dalam kebebasan menciptakan berbagai objek realitas dan tata nilai baru berdasarkan inspirasi agama.

Agama dan masyarakat memiliki hubungan yang erat. Di sini perlu diketahui bahwa ini tidak berarti mengimplikasikan pengertian "agama menciptakan masyarakat." Tetapi hal ini mencerminkan bahwa agama adalah merupakan implikasi dari perkembangan masyarakat. Hubungan antara agama dengan masyarakat terlihat di dalam masalah ritual. Dimana kesatuan masyarakat tradisional sangat tergantung kepada conscience collective (hati nurani kolektif), dan agama nampak memainkan peran ini. Masyarakat menjadi "masyarakat" karena fakta bahwa para anggotanya taat kepada kepercayaan dan pendapat bersama. Ritual, yang terwujud dalam pengumpulan orang dalam upacara keagamaan, menekankan pada kepercayaan mereka atas orde moral yang ada, dimana solidaritas mekanis itu bergantung. Di sini agama nampak sebagai alat integrasi masyarakat, dan praktek ritual secara terus menerus menekankan ketaatan manusia terhadap agama, yang ikut serta di dalam memainkan fungsi penguatan solidaritas.

\section{Fungsi Agama dalam Masyarakat}

Dalam pandangan sosiologis, perhatian utama terhadap agama adalah terletak pada fungsinya dalam masyarakat. Konsep fungsi seperti kita ketahui, menunjuk pada sumbangan atau kontribusi yang diberikan agama, atau lembaga sosial yang lain, untuk 
mempertahankan keutuhan masyarakat sebagai usaha-usaha yang aktif dan berlangsung secara terus-menerus.

Menurut Emile Durkheim sebagai sosiolog besar telah memberikan gambaran tentang fungsi agama dalam masyarakat. Dia berkesimpulan bahwa sarana-sarana keagamaan adalah lambang-lambang masyarakat, kesakralan bersumber pada kekuatan yang dinyatakan berlaku oleh masyarakat secara keseluruhan bagi setiap anggotanya, dan fungsinya adalah mempertahankan dan memperkuat rasa solidaritas dan kewajiban sosial.

Agama telah dicirikan sebagai pemersatu aspirasi manusia yang paling sublime, sebagai sejumlah besar moralitas, sumber tatanan masyarakat dan perdamaian batin individu, sebagai sesuatu yang memuliakan dan yang membuat manusia beradab. Sebenarnya lembaga keagamaan adalah menyangkut hal yang mengandung arti penting tertentu, menyangkut masalah aspek kehidupan manusia, yang dalam transendensinya, mencakup sesuatu yang memiliki arti penting dan menonjol bagi manusia.

Agama bukanlah suatu entitas independen yang berdiri sendiri. Tetapi agama terdiri dari berbagai dimensi yang merupakan satu kesatuan. Masingmasingnya tidak dapat berdiri tanpa yang lain. seorang ilmuwan barat menguraikan agama ke dalam lima dimensi komitmen. Seseorang kemudian dapat diklasifikasikan menjadi seorang penganut agama tertentu dengan adanya perilaku dan keyakinan yang merupakan wujud komitmennya. Ketidakutuhan seseorang dalam menjalankan lima dimensi komitmen ini menjadikannya religiusitasnya tidak dapat diakui secara utuh. Kelimanya terdiri dari perbuatan, perkataan, keyakinan, dan sikap yang melambangkan (lambing atau simbol) kepatuhan (komitmen) pada ajaran agama. Agama mengajarkan tentang apa yang benar dan yang salah, serta apa yang baik dan yang buruk.

Agama berasal dari Supra Ultimate Being, bukan dari kebudayaan yang diciptakan oleh seorang atau sejumlah orang. Agama yang benar tidak dirumuskan oleh manusia. Manusia hanya dapat merumuskan kebajikan atau kebijakan, bukan kebenaran. Kebenaran hanyalah berasal dari yang benar yang mengetahui segala sesuatu yang tercipta, yaitu Sang Pencipta itu sendiri. Dan apa yang ada dalam agama selalu berujung pada tujuan yang ideal. Ajaran agama berhulu pada kebenaran dan bermuara pada keselamatan. Ajaran yang ada dalam agama memuat berbagai hal yang harus dilakukan oleh manusia dan tentang hal-hal yang harus dihindarkan. Kepatuhan pada ajaran agama ini akan menghasilkan kondisi ideal. Mengapa ada yang Takut pada Agama?.

Mereka yang sekuler berusaha untuk memisahkan agama dari kehidupan seharihari. Mereka yang marxis sama sekali melarang agama. Mengapa mereka melakukan hal-hal tersebut? Kemungkinan besarnya adalah karena kebanyakan dari mereka sama sekali kehilangan petunjuk tentang tuntunan apa yang datang dari Tuhan. Entah mereka dibutakan oleh minimnya informasi yang mereka dapatkan, atau mereka memang menutup diri dari segala hal yang berhubungan dengan Tuhan.

Alasan yang seringkali anggota masyarakat kemukakan adalah agama memicu perbedaan. Perbedaan tersebut menimbulkan konflik. Mereka memiliki orientasi yang terlalu besar pada pemenuhan kebutuhan untuk bersenang-senang, sehingga mereka tidak mau mematuhi ajaran agama yang melarang mereka melakukan hal yang menurutnya menghalangi kesenangan mereka, dan mereka merasionalisasikan perbuatan irasional mereka itu dengan justifikasi sosialintelektual. Mereka menganggap segi intelektual ataupun sosial memiliki nilai keberhargaan yang lebih. Akibatnya, mereka menutup indera penangkap informasi yang mereka miliki dan hanya mengandalkan intelektualitas yang serba terbatas.

Masyarakat memahami dunia dalam batas rasio saja. Logika yang mereka miliki begitu terbatasnya, hingga abstraksi realita 
yang bersifat supra-rasional tidak mereka akui. Dan hasilnya, mereka terpenjara dalam realitas yang serba empiri. Semua harus terukur dan terhitung. Walaupun mereka sampai sekarang masih belum memahami banyaknya fungsi alam yang bekerja dalam mekanisme supra rasional, keterbatasan kerangka berpikir yang mereka miliki menegasikan semua hal yang tidak dapat ditangkap secara inderawi. Padahal, pembatasan diri dalam realita yang hanya bersifat empiri hanya akan membatasi potensi manusia itu sendiri. Dan hal ini menegasikan tujuan hidup yang selama ini diagungkan para penganut realita rasio saja, yaitu aktualisasi diri dan segala potensinya.

Agama, dengan sandaran yang kuat pada realitas supra rasional, membebaskan manusia untuk mengambil segala hal yang terbaik yang dapat dihasilkannya dalam hidup. Semua-apakah hal itu bersifat empiriterukur, maupun yang belum dapat diukur. Empirisme bukanlah suatu hal yang ditolak agama. Agama yang benar, yang bersifat universal, mencakup segi intelektual yang luas, yang diantaranya adalah empirisme. Agama tidak mereduksi intelektualitas manusia dengan membatasi kuantitas maupun kualitas suatu idea. Agama yang benar, memberi petunjuk pada manusia tentang bagaimana potensi manusia dapat dikembangkan sebesar-besarnya. Kesalahan yang dibuat para penilai agamalah yang kemudian menyebabkan realita ajaran ideal ini menjadi terlihat buruk. Beberapa peristiwa sejarah yang menonjol mereka identikan sebagai kesalahan karena agama. Karena keyakinan pada ajaran agama. Padahal, kerusakan yang ditimbulkan adalah justru karena jauhnya orang dari ajaran agama. Kerusakan itu timbul saat agama yang mengajarkan kemuliaan disalahgunakan oleh manusia pelaksananya untuk mencapai tujuan yang terlepas dari ajaran agama itu sendiri, dan terlepas dari pelaksanaan dimensi keseluruhan.

\section{Pelembagaan Agama Dalam Masyarakat}

Agama dalam kaitannya dengan lembaga sosial yang ada dalam masyarakat, maka seharusnya cara berpikir sosiologis dipusatkan pada lembaga-lembaga kecil dan besar, serta gabungan lembaga-lembaga yang merupakan sub-sub sistem dalam masyarakat. Para sosiolog cenderung untuk memperhatikan pola-pola interaksi yang terjadi dalam setiap institusi atau lembaga kemasyarakatan.

Pengelompokan lembaga-lembaga yang penting dapat dijabarkan ke dalam kategorikategori yang lebih kecil dan khusus), yakni: 1. Lembaga-lembaga poitik yang ruang lingkupnya adalag kekuasaan dan monopoli pada penggunaan kekuasaan secara sah.

2. Lembaga-lembaga ekonomi yang mencakup produksi dan distribusi barang atau jasa

3. Lembaga-lembaga integrative-ekspresif .

4. Lembaga-lembaga kekerabatan mencakup kaedah-kaedah yang mengatur hubungan sosial, biologis dan pengarahan terhadap golongan muda.

Walaupun tampaknya, suatu lembaga memusatkan perhatian terhadap suatu aspek kemasyarakatan tertentu, namun di dalam kenyataan lembaga-lembaga tersebut saling berkaitan secara fungsional. Setiap lembaga berpartisipasi dan memberikan kontribusi dengan cara-cara tertentu pada kehidupan masyarakat setempat ("community").

Sejarah mencatat bahwa tidak jarang terjadi peralihan sebab terpaksa. Pemaksaan terjadi melalui "perselingkuhan" antara lembaga agama dengan lembaga kekuasaan. Keduanya mempunyai kepentingan. Pemerintah butuh ketentraman sedangkan lembaga agama membutuhkan penganut atau pengikut. Kerjasama atau lebih tepat disebut saling memanfaatkan itu terjadi sejak dahulu kala. Para penyiar agama sering membonceng pada suatu kekuasaan (kebetulan menjadi penganut agama tersebut) yang mengadakan invansi ke daerah lain. Penduduk daerah atau negara yang baru ditaklukkan itu dipaksa suka atau tidak suka menjadi penganut agama penguasa baru. Bahkan sejarah menunjukkan bahwa lembaga-lembaga keagamaan 
merupakan bentuk asosiasi manusia yang paling mungkin untuk terus bertahan.

Kaitannya dengan lembaga sosial yang ada dalam masyarakat, hendaknya cara berpikir sosiologis dipusatkan pada lembaga-lembaga kecil dan besar, serta gabungan lembaga-lembaga yang merupakan sub-sub sistem dalam masyarakat. Para sosiolog cenderung untuk memperhatikan paling sedikit.

Kasus-kasus itu tidak hanya terjadi di Indonesia atau Asia dan Afrika pada umumnya tetapi juga terjadi di Eropa pada saat agama monoteis mulai diperkenalkan. Di Indonesia "tradisi" saling memanfaatkan berlanjut pada zaman orde Baru.Pemerintah orde baru tidak mengenal penganut di luar lima agama resmi. Inilah pemaksaan tahap kedua. Penganut di luar lima agama resmi, termasuk penganut agama suku, terpaksa memilih salah satu dari lima agama resmi versi pemerintah. Namun ternyata masalah belum selesai. Kenyataannya banyak orang yang menjadi penganut suatu agama tetapi hanya sebagai formalitas belaka. Dampak keadaan demikian terhadap kehidupan keberagaan di Indonesia sangat besar. Para penganut yang formalitas itu, dalam kehidupan kesehariannya lebih banyak mempraktekkan ajaran agam suku, yang dianut sebelumnya, daripada agama barunya. Pra rohaniwan agama monoteis, umumnya mempunyai sikap bersebrangan dengan prak keagamaan demikian. Lagi pula pengangut agama suku umumnya telah dicap sebagai kekafiran. Berbagai cara telah dilakukan supaya praktek agama suku ditinggalkan, misalnya pemberlakukan siasat/disiplin gerejawi. Namun nampaknya tidak terlalu efektif. Upacara-upacara yang bernuansa agama suku bukannya semakin berkurang tetapi kelihatannya semakin marak di mana-mana terutama di desa-desa.

Demi pariwisata yang mendatangkan banyak uang bagi para pelaku pariwisata, maka upacarav-upacara adat yang notabene adalah upacara agama suku mulai dihidupkan di daerah-daerah. Upacaraupacara agama sukuyang selama ini ditekan dan dimarjinalisasikan tumbuh sangat subur bagaikan tumbuhan yang mendapat siraman air dan pupuk yang segar. Anehnya sebab bukan hanya orang yang masih tinggal di kampung yang menyambut angin segar itu dengan antusias tetapi ternyata orang yang lama tinggal di kotapun menyambutnya dengan semangat membara. Bahkan di kotakota pun sering ditemukan praktik hidup yang sebenarnya berakar dalam agama suku. Misalnya pemilihan hari-hari tertentu yang diklaim sebagai hari baik untuk melaksanakan suatu upacara. Hal ini semakin menarik sebab mereka pada umumnya merupakan pemeluk agama yang "fanatik" dari salah satu agama monoteis bahkan pejabat atau pimpinan agama tertentu.

\section{Pengaruh Agama Dalam Kehidupan Masyarakat}

Setiap umat atau kelompok yang benarbenar hidup sesuai dengan amanah agamanya masing-masing. Oleh karena itu, maka dengan sendirinya akan terwujud kerukunan, persaudaraan, kedamaian dan kenyamanan dalam kehidupan bermayarakat. Karena agama telah mengajarkan kebenaran dan kebaikan dan menjauhkan dari segala keburukan, pertikaian, diskriminasi dan lain sebagainya. Hidup beragama tampak pada sikap dan cara perwujudan sikap hidup beragama seseorang yang mampu menerima sesama yang beragama apapun sebagai hamba Allah SWT. Karena keyakinan bahwa Allah SWT yang Maha Pengasih lagi Maha Penyayang mengasihi setiap manusia dan seluruh umat manusia tanpa diskriminasi, maka dia pun wajib dan tak punya pilihan lain, selain mengasihi sesamanya tanpa adanya diskriminasi, baik berdasarkan agama, budaya, etnik, profesi, atau kepentingan tertentu yang berbeda.

Seseorang yang tulus dalam beragama, akan menghormati, menghargai dan bahkan mengasihi dan merahmati sesamanya. Karena sesamanya adalah manusia yang dikasihi oleh Allah SWT. Seseorang yang tulus beragama mengasihi sesamanya hanya 
dengan berpamrih pada Allah SWT, sebagai segala sumber kasih dan rahmat.

Membedakan diri sendiri dengan orang lain adalah perbuatan akal sehat, tetapi melakukan diskriminasi terhdap orang lain justru bertentangan dengan akal sehat dan nilai kemanusiaan yang dijunjung tinggi oleh para umat beragama dari setiap agama yang saling berbeda. Sebagai umat yang beragama, sudah sepatutnya kita menjadi contoh terbaik bagi umat manusia sedunia dengan cara hidup yang saling mengasihi dan saling menghargai dengan menerima perbedaan agama sebagai rahmat Allah SWT.

\section{PENUTUP}

1) Agama, budaya dan masyarakat saling berkaitan dan dibuktikan dengan pengetahuan agama yang meliputi penulisan sejarah dan figur nabi dalam mengubah kehidupan sosial. Argumentasi rasional tentang arti dan hakikat kehidupan, tentang Tuhan dan kesadaran akan kematian menimbulkan relegi, dan sila Ketuhanan Yang Maha Esa sampai pada pengalaman agamanya para tasauf.

2) Agama merupakan tempat mencari makna hidup yang final dan ultimate. Dan pada gilirannya agama yang diyakini merupakan sumber motivasi tindakan individu dalam hubungan sosial dan kembali kepada konsep hubungan agama dengan masyarakat, di mana pengalaman keagamaan akan terefleksikan pada tindakan sosial dan individu dengan masyarakat yang seharusnya tidak bersifat antagonis.

3) Hubungan agama, kebudayaan dan masyarakat serta agama berfungsi sebagai alat pengatur pengontrol dan sekaligus membudayakannya dalam arti mengungkapkan apa yang ia percaya dalam bentuk-bentuk budaya yaitu dalam bentuk etis, seni bangunan, struktur masyarakat, adat istiadat dan lain-lain.

4) Pengaruh timbal balik antara agama dan budaya, dalam arti agama mempengaruhi kebudayaan, kelompok masyarakat, suku bangsa. Kebudayaan cenderung meng- ubah keaslian agama sehingga menghasilkan penafsiran berlainan.

5) Agama dan Budaya memiliki keterhubungan yang erat, yakni agama berperan sebagai konsepsi budaya dan sebagai realitas budaya yang terdapat di Indonesia.

6) Budaya merupakan hasil dari interaksi antara manusia dengan segala isi yang ada di alam raya ini. Dengan kemampuan akal pikiran yang dimiliki oleh manusia maka manusia mampu menciptakan suatu kebudayaan.

7) Kebudayaan digunakan untuk memahami agama yang tampil dalam bentuk formal yang menggejala di masyarakat.

8) Keragaman budaya atau "cultural diversity" adalah keniscayaan yang ada di bumi Indonesia yang tidak dapat dipungkiri keberadaannya. Dengan keanekaragaman kebudayaan Indonesia dapat dikatakan memiliki keunggulan dibandingkan dengan negara lain, di mana Indonesia mampu menghasilkan potret kebudayaan yang lengkap dan bervariasi.

\section{DAFTAR PUSTAKA}

Andito, 1998, Atas Nama Agama, Wacana Agama Dalam Dialog Bebas Konflik, Pustaka Hidayah: Bandung

Anshari, Saifuddin Endang. 2004. Wawasan

Islam: Pokok-pokok Pikiran Tentang

Paradigma dan Sistem Islam, : Gema Insani, 2004. ISBN.

Azyumardi Azra, 1999, Konteks Berteologi

di Indonesia: Pengalaman Islam,

Paramadina: Jakarta

Badri Yatim, 2006, Sejarah Peradaban Islam, Raja Grafindo Persada: Jakarta

Dadang Kahmad, 2004. Sosiologi Agama, Suatu Pengantar, Gramedia Press, Jakarta.

Durkheim, Emile, 1954, The Elementary Forms of The Religious Life. trans. By Joseph Ward Swain (Glencoe, III : The Free Press, George Allen \& Unwin Ltd.

Elizabet K. Nottingham, 1985. Agama dan Masyarakat: Suatu pengantar 
Sosiologi agama, Jakarta, CV. Rajawali Press.

Geertz, Clifford, 1992, Kebudayaan dan Agama, Kanisius: Yogyakarta

Hamka, 1975, Sejarah Umat Islam IV, Bulan Bintang: Jakarta

Hasan Muarif Ambary, 1998, Menemukan Peradaban Islam: Arkeologi dan Islam di Indonesia: Pusat Penelitian Arkeologi Nasional: Jakarta

Hendropuspito, 1988, Sosiologi Agama, Kanisius, Yogyakarta

Joeyz, Iwan. Hubungan Agama dan Budaya. Http://ukpkstain.multiply.com/journal/ item/49. Diakses tanggal 1 Desember 2009.

Koentjaraningrat, 1980, Pokok-Pokok Antropologi Sosial, Penerbitan Universitas: Jakarta

Koentjaraningrat, 1990, Pengantar Ilmu Antropologi, Jakarta: PT Ranaka Cipta.

O’Dea, Thomas F., 1986, Sosiologi Agama, Kanisius, Yogyakarta

Masjkoery, A. Qohar, et al. 2003.

Pendidikan Agama Islam. Jakarta :

Universitas Gunadarma,

Max Webber, 1963, The Sociology of Religion,trans. By Ephraim Fischoff Beacon Press, Boston
Mulyono Sumardi, 1982, Penelitian Agama, Masalah dan Pemikiran, Pustaka Sinar Harapan: Jakarta

Poerbatjaraka, R, Ng, 1952, Riwayat Indonesia I, Yayasan Pembangunan: Jakarta

Septiadi, Rio. 2009. Kebudayaan Islam Makalah Pendidikan Agama Islam. rioseptiadi.multiply.com. [Online] Mei 17, 2009. [Cited: Maret 23, 2011.]

Suwarno,dkk.2008,.Ilmu Social Budaya Dasar.Surakarta:BP/FKIP UMS

Soerjanto Poespowardoyo, 1986, Pengertian Local Genius dan Relevansinya Dalam Modernisasi, "Kepribadian Budaya Bangsa (local genius)", Pustaka Jaya: Jakarta

Thomas F.o'dea, Sosiologi Agama Suatu Pengenalan Awal, Jakarta, CV. Rajawali Press, 1985.

Widyastini. 2004. Nilai-nilai Islam dalam Kebudayaan, Yogyakarta : Jurnal Filsafat, 2004, Vol. II.

Wikipedia. 2011. Budaya. Wikipedia. [Online] Maret 11, 2011. [Cited: Maret 23, 2011.] http://id.wikipedia.org/wiki/Budaya. 